\title{
Erratum to: Elevated carbon dioxide has the potential to impact alarm cue responses in some freshwater fishes
}

\author{
John A. Tix $\cdot$ Caleb T. Hasler $\cdot$ Cody Sullivan $\cdot$ Jennifer D. Jeffrey $\cdot$ Cory D. Suski
}

Published online: 30 November 2016

(C) Springer Science+Business Media Dordrecht 2016

\section{Erratum to: Aquat Ecol \\ DOI 10.1007/s10452-016-9598-8}

In the original publication of the article, corresponding author's name was misspelt. The correct name is given in this erratum.

The original article was corrected

The online version of the original article can be found under doi:10.1007/s10452-016-9598-8.

J. A. Tix · C. T. Hasler . C. Sullivan .

J. D. Jeffrey · C. D. Suski $(\bowtie)$

Department of Natural Resources and Environmental

Sciences, University of Illinois Urbana-Champaign,

W-503 Turner Hall, 1102 South Goodwin Ave, Urbana,

IL 61801, USA

e-mail: suski@illinois.edu 